\title{
THE SCOPE OF SECTION 75(V) OF THE CONSTITUTION: WHY INJUNCTION BUT NO CERTIORARI?
}

\author{
The Hon William Gummow AC*
}

\begin{abstract}
The course of judicial decisions given pre-federation in the United States and England where the remedy of certiorari or of injunction was granted or refused against public officers assists an understanding of the apparent oddity in the omission of certiorari and the inclusion of injunction in the remedies specified in s 75(v) of the Constitution. Further, the significance of the inclusion of the injunction has yet to be fully examined in the case law dealing with s $75(\mathrm{v})$.
\end{abstract}

\section{INTRODUCTION}

Alone of the nine heads of federal jurisdiction in ss 75 and 76 of the Constitution, s 75(v) is concerned specifically with remedies. However, s 75(v), in using the terms 'a writ of Mandamus or prohibition or an injunction', cannot be read as if written upon a blank slate. Like certiorari, these were particular remedies which before Federation had been developed in the courts of common law and of equity. However, their inclusion in s 75(v) and the omission of certiorari ensured that in Australia many questions of administrative law remedy pose issues of constitutional law.

From time to time it is suggested that s $75(\mathrm{v})$ was included in Ch III for more abundant caution, to ensure that the High Court not lack that original jurisdiction, whose absence in the Supreme Court of the United States had determined the actual result in Marbury v Madison. ${ }^{1}$ It also is suggested that s 75(v) is surplus to requirements, because officers of the Commonwealth would always be persons being sued on behalf of the Commonwealth and thus any application under s 75(v) would fall within the general terms of s 75(iii).

One may accept the first point but it does not illuminate the subject of this paper, the choice of particular remedies in drawing s 75(v). The second, with its focus upon the apparent amplitude of s 75(iii), requires fuller attention.

It is a general principle of textual construction that the conferral of an explicit but limited power or authority by one provision excludes the operation of a generally

* This paper was first presented at the Public Law Weekend organised by the Centre for International and Public Law, ANU College of Law on 15 November 2013. The writer is indebted to the Commonwealth Solicitor-General, Mr Justin Gleeson SC, for his commentary on this paper in its original form.

15 US (1 Cranch) 137 (1803). 
expressed provision in the same text; for the taking of relevant actions there is only the explicit power, with its attendant limitations. ${ }^{2}$ That proposition does not hold good for the interpretation of s 51 of the Constitution, in particular with respect to the relationship between the various heads of legislative power listed in that section. The Work Choices Case, $^{3}$ in its treatment of paras (xx) and (xxxv), provides a recent illustration. But it does not necessarily follow that $\mathrm{s} 75$ is to be read in the same way as s 51 . Hence the attention to $\mathrm{s} 75(\mathrm{v})$ in what follows.

\section{THE THESIS OF THIS PAPER}

The thesis of this paper is that: (a) at the time of Federation the reach of certiorari was understood both in the United States and England as limited to decisions which were 'judicial' rather than 'administrative'; (b) the phrase 'officers of the Commonwealth' was apt to refer to decision-making by non-judicial officers; (c) the injunction was used both in the United States and England to restrain injury to the rights of the plaintiff by administrative decisions tainted by abuse of power; (d) certiorari had another relevant characteristic in its application to errors of law which, while they had to appear on the face of the record, need not be jurisdictional errors; and (e) thus, to have included certiorari would have risked constitutional entrenchment of judicial review of the activities of Commonwealth officers acting with the authority conferred by valid federal laws; but (f) to this day it remains a matter of debate how far the inclusion of the injunction in s 75(v) has entrenched judicial review for abuses of power which, however, are not in excess of jurisdiction.

\section{'OFFICERS OF THE COMMONWEALTH'}

Section 64 of the Constitution indicates that Ministers of State are officers of the Commonwealth charged with the administration of departments of State of the Commonwealth, and, in so doing to execute and maintain the laws of the Commonwealth. Until Parliament otherwise provides (eg by the Public Service Act 1999 (Cth)), the appointment of all other officers of the executive government is vested in the Governor-General in Council, or its delegate or some other authority provided by a law of the Commonwealth (s 67). In this setting, s 75(v) is readily seen as dealing with the relationship between the executive and judicial branches of the Commonwealth body politic.

But what of judges of the High Court and other courts, being those created by the Parliament? Are they 'officers of the Commonwealth' within the meaning of s 75(v)? Or, are they to be supervised through the appellate structure established by paras (i) and (ii) of s 73 of the Constitution?

What is now long familiarity with the 'appeal' process in s 73 may obscure what in 1900 were its recent origins in the unified court structure established in England by the Judicature System. The 'appeal' as understood in Chancery was developed and extended to replace what in the common law courts had been the means of review of the

2 Minister for Immigration and Multicultural and Indigenous Affairs v Nystrom (2006) 228 CLR 566, 586-9 [52]-[59]; Perry Herzfeld, Thomas Prince and Stephen Tully, Interpretation and Use of Legal Sources: The Law of Australia (Thomson Reuters, 2013) § 25.1.1860-70.

$3 \quad$ New South Wales $v$ Commonwealth (2006) 229 CLR 1. 
outcome of jury trials, in particular the writ of error. ${ }^{4}$ The writ of error had been abolished by the Supreme Court of Judicature Act $1875 .^{5}$

The writ of error had run only to a judgment pronounced after a trial in the course of common law procedure. In civil cases this involved an action commenced by writ and followed by pleadings; in criminal cases this involved an indictment or its equivalent. For the more informal proceedings in inferior courts, to which the writ of error did not run, certiorari lay to quash the proceedings; 6 in general, prohibition controlled proceedings flawed for want or excess of jurisdiction; mandamus lay to compel the exercise of jurisdiction.

Hence the force of the position taken by Isaacs J dissenting in $R v$ Commonwealth Court of Conciliation and Arbitration; Ex parte Whybrow \& Co. ${ }^{7}$ This was that the writs described above had been understood in England as 'appellate' rather than 'original' jurisdiction, that s 75(v) was addressed to 'officers' not 'courts', and it was s 73 which provided exhaustively for the appellate jurisdiction of the High Court with respect, inter alia, to other federal courts. But, as we know this was not the view of the majority in Whybrow; the result has been regretted but never, in terms, repudiated by the High Court. ${ }^{8}$

Consistently with the view of Isaacs J in Whybrow, certiorari would have been considered inappropriate in a provision concerned with non-judicial officers.

But, as matters stand, while certiorari may issue as ancillary to a grant of prohibition and mandamus, ${ }^{9}$ remedies going to jurisdiction, its omission from $\mathrm{s} 75(\mathrm{v})$ as a primary remedy has long been the subject of discussion. ${ }^{10}$ Further consideration is assisted by looking to the position respecting certiorari (and injunction) in the United States when the Commonwealth of Australia was in its formation.

\section{CERTIORARI AND INJUNCTION IN THE UNITED STATES}

The immediate issue in Degge $v$ Hitchcock ${ }^{11}$ was whether the US Postmaster-General had 'acted in a judicial capacity' and 'exceeded his jurisdiction' in ordering that mail addressed to Degge and corporations of which he was president be returned to the sender and marked 'Fraudulent', so that certiorari should issue.

The Supreme Court stated that certiorari ran to 'boards ... officers, tribunals, and inferior judicatures whose findings and decisions, even though erroneous, had the quality of final judgment', and added that:

[I]n all those cases, [certiorari] ran from court to court, including boards, officers or tribunals having a limited statutory jurisdiction, but whose judgments would be conclusive unless set aside.

\footnotetext{
4 CDJ v VAJ (1998) 197 CLR 172, 196-7 [95]-[96]; DJL v Central Authority (2000) 201 CLR 226, 245-6 [33]-[37].

538 \& 39 Vict, c 77, Section 33, Sched; RSC O.58, r1. As to motions for a new trial, after verdict, see John Fairfax Publications Pty Ltd v Gagic (2007) 230 CLR 291, 299-301 [21]-[24].

6 Lord Halsbury (ed Laws of England (Butterworth, 1909) vol 10, 160-1.

7 (1910) 11 CLR 1, 48-9 ('Whybrow').

8 See Mark Leeming, Authority to Decide (Federation Press, 2012) 284.

9 Plaintiff S157/2002 v Commonwealth (2003) 211 CLR 476, 507

10 See, eg, L J W Aitken, 'The High Court's Power to Grant Certiorari - The Unresolved Question' (1986) 16 Federal Law Review 370.

11229 US 162, 170-1 (1913) ('Degge').
} 
The decision of the Supreme Court in Degge was that the order by the PostmasterGeneral was for protection of the public and therefore had "an administrative quality" which was "sufficient to prevent it from being subject to review by writ of certiorari." However, the court added that 'had there been an arbitrary exercise of statutory power, or a ruling in excess of the jurisdiction conferred, [the appellants] had the right to apply for and obtain appropriate relief in a court of equity.' The authorities cited included American School of Magnetic Healing $v$ McAnnulty, 12 in which an injunction had issued to prohibit further withholding by the Postmaster-General of mail from the complainants, there being 'no adequate remedy at law' for the consequent damage to their business. ${ }^{13}$

May there be found here one ground upon which, with respect to officers of the new Commonwealth, it might well have been considered that certiorari would be an inadequate or inappropriate remedy, and that the injunction would restrain activities in excess of jurisdiction? The position had been reached in the United States, well before federation, that where there was a threat to violate 'a plain official duty' by what was 'some positive official act' then 'any person who will sustain personal injury thereby for which adequate compensation cannot be had at law may have an injunction to prevent it.' 14

However, throughout the $1^{\text {th }}$ century reliance was placed by the Supreme Court upon Marbury $v$ Madison 15 for a distinction of general application between official acts involving the exercise of judgment or discretion and those which were purely ministerial. Thus, in Noble $v$ Union River Logging Railroad $\mathrm{Co}^{16}$ it was said by the Court in 1893:

$[W] i t h$ respect to the former, there exists, and can exist, no power to control the executive discretion, however erroneous its exercise may seem to have been; but with respect to ministerial duties, an act or refusal to act is, or may become, the subject of review by the courts.

Numerous decisions were cited by the Court in Noble where 'the distinction between judicial and ministerial acts is commented upon and enforced.'

In Marbury $v$ Madison, Marshall CJ had supported the engagement of the judicial power, by a distinction he drew as follows: ${ }^{17}$

[W] here the heads of departments are the political or confidential agents of the Executive $\ldots$ to act in cases in which the Executive possesses a constitutional or legal discretion ... their acts are only politically examinable. But where a specific duty is assigned by law, and individual rights depend upon the performance of that duty, it seems equally clear that the individual who considers himself injured has a right to resort to the laws of his country for a remedy.

12187 US 94 (1902).

13 Ibid 110

14 Board of Liquidation v McComb, 92 US 531, 541 (1875). See also Johnson v Towsley, 80 US (13 Wall) 72, 83-7 (1871); Noble v Union River Logging Railroad Co, 147 US 165, 172 (1893); and Jerry Mashaw, 'Federal Administration and Administrative Law in the Gilded Age' (2010) 119 Yale Law Journal 1362, 1400-2.

155 US (1 Cranch) 137 (1803).

16147 US 165, $171(1893)\left({ }^{\prime}\right.$ Noble').

175 US (1 Cranch) 137, 166 (1803). 
This reasoning has been seen as supplying a root for what in the United States has become the much debated 'political question' doctrine. ${ }^{18}$ In its time it represented a cautious approach by the Supreme Court to the scope of judicial review. ${ }^{19}$

As it happens, the reasoning in Marbury $v$ Madison set out above was to be little different from that 30 years later in Ellis $v$ Earl Grey. ${ }^{20}$ Shadwell V-C overruled a demurrer to a bill in Chancery seeking to enjoin the Lords of the Treasury Prime Minister, Lord Grey, being First Lord) from paying compensation provided by statute upon abolition of the office of Side Clerk in the Court of Exchequer, until determination of the entitlement to the compensation between several claimants; the Vice Chancellor emphasised that the injunction would not interfere with any discretion the Lords exercised in their public capacity and that the statute provided for a mere ministerial act in paying out the compensation sum.

The troubled 'political question' doctrine apart, in the 19 $9^{\text {th }}$ century a 'presumption of unreviewability' was supported in the United States as a matter of statutory construction. It was said by the Supreme Court in Martin $v$ Mott ${ }^{21}$ to be 'a sound rule of construction' that a statute conferring a discretionary power to be exercised upon an opinion of certain facts constitutes the repository of the power 'the sole and exclusive judge of the existence of those facts.'

This insulation of exercises of discretion from judicial review did not survive in the United States. The Administrative Procedure Act, ${ }^{22}$ enacted in 1946, draws within the scope of review actions, findings and conclusions which are 'arbitrary', 'capricious' or 'an abuse of discretion'.23 Moreover, declaratory and injunctive relief provide an important supplement to statutory review of federal agency action. ${ }^{24}$

What then may be drawn from the state of judicial review in the United States at the time of federation to throw light upon the omission from s 75(v) of certiorari and the inclusion of the injunction?

First, certiorari was understood as limited in its reach to decisions which were 'judicial' rather than 'administrative' in character. Secondly, the injunction was not limited by such a distinction. The emphasis there was upon apprehended injury to the rights of the plaintiff and the inadequacy of other remedies.

\section{CERTIORARI IN ENGLAND}

In England the constitutional structure lacked the strength supplied by a written constitution providing for the separation of powers. However, since at least the 17th century ${ }^{25}$ certiorari issued to remove the determinations not just of inferior courts (to which the writ of error did not run) but of bodies which were entrusted by statute or

18 Charles Alan Wright and Mary Kay Kane, Law of Federal Courts (West Group, 6th ed, 2002) § 14; Erwin Chemerinsky, Federal Jurisdiction (Aspen Publishers, 5th ed, 2007) § 2.6.1.

19 See the discussion of this part of the Marbury $v$ Madison judgment in George Haskins and Herbert Johnson, History of the Supreme Court of the United States (Macmillan, 1981) vol 2, 193 6.

(1833) 6 Sim 214; 58 ER 574.

25 US (12 Wheat) 19, 29 (1827).

Now found scattered throughout 5 USC.

5 USC § 706.

Richard Pierce, Administrative Law Treatise (Aspen Publishers, 5th ed, 2010), vol 3, § 18.4.

Lord Halsbury, above n 7, 160-1. 
royal charter with functions which might be described as 'judicial'. In 1699 Holt CJ had declared that 'where a man [such as the censors of the College of Physicians] has power to inflict imprisonment on another for punishment of his offence, then he hath judicial authority'.26

Some of the late 19th century English authorities took a further tack. They distinguished conclusions formed by a licensing body in the exercise of its administrative authority, to which certiorari was not attracted, from decisions in its 'judicial' activities. ${ }^{27}$

In the section of their work Judicial Review of Administrative Action which is headed 'Loosening certiorari's historical links to judicial functions', ${ }^{28}$ Aaronson, Dyer and Groves speak of this requirement that a person be under a duty to act 'judicially' as a 'new test', albeit influenced by the previous association of certiorari with bodies which looked like courts. ${ }^{29}$

In $R v$ Woodhouse Fletcher Moulton LJ then sought in 1906 to put the distinction on a principled basis as follows: 30

The writ of certiorari is a very ancient remedy, and is the ordinary process by which the High Court brings up for examination the acts of bodies of inferior jurisdiction. In certain cases the writ of certiorari is given by statute, but in a large number of cases it rests on the common law. It is frequently spoken of as being applicable only to 'judicial acts', but the cases by which this limitation is supposed to be established shew that the phrase judicial act' must be taken in a very wide sense, including many acts that would not ordinarily be termed 'judicial'.

The true view of the limitation would seem to be that the term 'judicial act' is used in contrast with purely ministerial acts. To these latter the process of certiorari does not apply, as for instance to the issue of a warrant to enforce a rate, even though the rate is one which could itself be questioned by certiorari. In short, there must be the exercise of some right or duty to decide in order to provide scope for a writ of certiorari at common law.

In this respect, then, in the federation period the course of English decisions upon certiorari resembled that in the United States. It indicated that acts of officers of the Commonwealth which were in excess of their authority but not of a 'judicial' character would not attract certiorari.

Thereafter, in $R v$ Macfarlane; Ex parte $O^{\prime}$ Flanagan and $O^{\prime}$ Kelly, ${ }^{31}$ Starke J referred to the English decisions, including the judgment of Fletcher Moulton LJ, for the proposition that, 'wide as is its scope', certiorari issued 'in respect of proceedings in their nature judicial as opposed to proceedings in their nature administrative or advisory.'

If, as suggested above, the officers identified in s 75(v) would not be exercising judicial power, what would be the scope for certiorari in respect of their activities?

That consideration would not apply to the use of the injunctive remedy against Commonwealth officers.

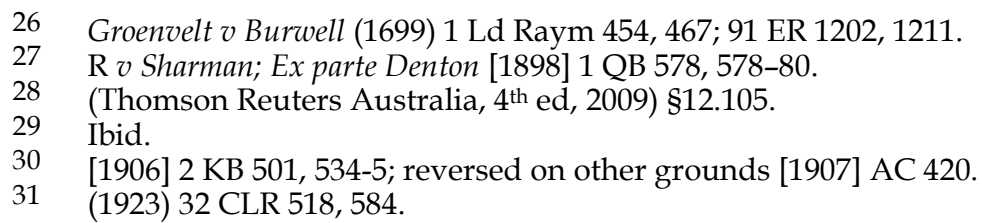




\section{THE INJUNCTION IN ENGLISH PUBLIC LAW}

Here again, the $19^{\text {th }}$ century English cases had followed a path resembling that in the United States. In England the emphasis in the decisions tended to be not so much upon the juristic or ministerial character of the power in question, as upon the impact of its exercise upon public or private rights, the inadequacy of damages at law, and the technicalities of the prerogative writs.

Two legislative developments associated with the growth of a recognisably modern state apparatus stimulated the English courts of equity.

The first concerned local government. The Municipal Corporations Act $1835^{32}$ was held to subject borough funds to the control of the Court of Chancery. The municipal corporations were assimilated by the equity judges to the position of trustees and this brought with it the equitable remedies to prevent or redress breaches of trust. The process began with the decision of Lord Cottenham LC in A-Gv Aspinall 33 and by the time Joyce published his work on injunctions in 1872, the subject of municipal corporations occupied 13 pages. ${ }^{34}$ Proceedings to restrain breaches of trust were by information laid by the Attorney-General at the relation of the rate payers; the essential question was whether, within the meaning of the statute, the challenged expenditure was for 'the public benefit of the inhabitants and the improvement of the Borough'. ${ }^{35} \mathrm{In}$ this way, what is classified as the application of ultra vires doctrine to public authorities assimilated the trust law respecting dispositions beyond the powers of the trustee.

But the breaches of trust restrained by injunction were not limited to mere absence of power; they extended to abuse of power. What did this hold for the future development of the injunction in public law? It may be observed immediately that the attribution to public officers of fiduciary responsibilities has been accepted in the modern case law. 36

The $19^{\text {th }}$ century development was the proliferation of statutory bodies with powers of injurious affectation of private rights, particularly those of landowners. The analogy relied upon to found injunctive relief was stated by Stuart V-C in A-G v Bishop of Manchester as follows: ${ }^{37}$

The acts of public functionaries who exceed the bounds of their authority by assuming power over property which the law does not give them, whether they be corporations or individuals, are treated as acts of private persons dealing without legal authority.

325 \& 6 Will 4, c 76. See generally William Cornish, J Stuart Anderson, Ray Cocks et al, The Oxford History of the Laws of England (Oxford University Press, 2010) vol 10, pt 2, 429-7.

33 (1837) 2 My \& Cr 613; 40 ER 773.

34 William Joyce, The Law and Practice of Injunctions in Equity and at Common Law (R Clarke \& Company, 1872) vol 1, ch 5, pt 1, s 1 .

35 A-G v Corporation of Norwich (1848) 16 Sim 225; 60 ER 860.

36 Reading $v$ The King [1949] 2 KB 232; Reading $v$ A-G [1951] AC 507; Federal Commissioner of Taxation v Day (2008) 236 CLR 163, 180-1 [34].

37 (1867) LR 3 Eq 436, 455. 
In Frewin $v$ Lewis, ${ }^{38}$ Lord Cottenham LC referred to the disputed exercise of powers by railway and canal corporations and other statutory bodies and said of them:

If, under presence of an authority which the law does give them to a certain extent, they go beyond the line of their authority, and infringe or violate the rights of others, they become, like all other individuals amenable to the jurisdiction of the court by injunction.

Four points should be made respecting this line of cases. First, the occasion for equitable intervention was action, or threatened action, beyond power; the analogy with jurisdictional error will be apparent. Secondly, many of the powers exercised by the public authorities could not be classified as judicial in character, but the difficulty with the use of certiorari to supervise ministerial activity did not apply to the injunction. Thirdly, the injunction protected rights of property in a specific rather than a loose sense. Finally, while an injunction might be refused if there were another and adequate remedy, the development of the interim injunction with the power to suspend or postpone injunctive relief and the efficiency of the procedures in Chancery after the reforms of the $1850 \mathrm{~s}^{39}$ favoured equitable relief over that under the prerogative writs.

Thus, at the time of federation the state of the case law in England and in the United States indicated the utility of injunction rather than certiorari as a remedy against officers of the Commonwealth.

\section{CERTIORARI - A FURTHER COMPLICATION}

Certiorari had another relevant characteristic, one which set it apart from remedies concerned with excess of jurisdiction. This was its application to errors of law on the face of the record, errors which need not be jurisdictional errors.

In 1879 Lord Cairns LC had described this use of certiorari as follows: 40

If the Court of Quarter Sessions stated upon the face of the order, by way of recital, that the facts were so and so, and the grounds of its decision were such as were so stated, then the order became upon the face of it, a speaking order; and if that which was stated upon the face of the order, in the opinion of any party, was not such as to warrant the order, then that party might go to the Court of Queen's Bench and point to the order as one which told its own story, and ask the court of Queen's Bench to remove it by certiorari, and when so removed to pass judgment upon it, whether it should or should not be quashed.

Subsequently in $R v$ Nat Bell Liquors Ltd, the Privy Council referred to that passage, emphasising the supervision by certiorari not only of matters of jurisdiction but also of 'the observance of the law in the course of its exercise'. ${ }^{41}$ More recently, the High Court in Kirk v Industrial Court (NSW) ${ }^{42}$ pointed out the unresolved tension between these two grounds for relief; the Court also ${ }^{43}$ emphasised that in Australia the step taken by the

$38 \quad$ (1838) 4 My \& Cr 249, 255; 41 ER 98, 100.

39 See Mark Leeming, 'Five Judicature Fallacies' in Justin Gleeson, J A Watson and Ruth Higgins (eds), Historical Foundations of Australian Law (Federation Press, 2013) vol 1, 169, 171 403. Overs

40.

41 [1922] 2 AC 128, 155-6.

42 (2010) 239 CLR 531, 567-8.

43 (2010) 239 CLR 531, 571 [65]. 
House of Lords in $R v$ Hull University Visitor; Ex parte Page in $1993^{44}$ had not been followed; in effect, the House of Lords collapsed error of law and jurisdictional error.

To have included certiorari in s $75(\mathrm{v})$ would have risked constitutional entrenchment of judicial review of the activities of Commonwealth officers, who had acted within their jurisdiction conferred by valid laws made by the Parliament.

\section{POST-FEDERATION DEVELOPMENTS}

Something should be added respecting the development of the injunctive remedy in Australian public law in the $20^{\text {th }}$ century. First, it was taken for granted from the earliest days of federation that the expression 'officers of the Commonwealth' included Ministers who were exercising powers conferred upon them by or under statute. In Ferrando $v$ Pearce 45 the Court was divided on the grant of an interlocutory injunction against Minister Pearce to restrain deportation of the plaintiff, but it did so on issues to do with prima facie case, rather than the amenability of the Minister to injunctive relief. There was thereby avoided for the Commonwealth that unwelcome feature of United Kingdom law associated with the long running difficulties in enjoining Ministers of the Crown from unlawful action. ${ }^{46}$

Secondly, there has been relaxation of the requirements for standing to support direct action without the relation of the Attorney-General. It is now settled that where the issue is whether federal jurisdiction has been invoked with respect to one or more of the 'matters' identified in ss 75 and 76 of the Constitution, questions of standing are subsumed within that issue. ${ }^{47}$ Indeed, it was said in Bateman's Bay Aboriginal Land Council v Aboriginal Community Benefit Fund Pty Ltd ${ }^{48}$ as a general consideration the principles by which standing is assessed are directed to marking out the boundaries of judicial power, 'whether [this be] in federal jurisdiction or otherwise'; reference for this proposition was made to what had been said in Ainsworth $v$ Criminal Justice Commission 49 by Mason CJ, Dawson, Toohey, Gaudron JJ and by Brennan J respectively.

Thirdly, what of the use of the injunction to restrain abuses of power which do not involve jurisdictional error? In the joint reasons in Plaintiff S157/2002 v Commonwealth, ${ }^{50}$ their Honours said 'injunctive relief would clearly be available for fraud, bribery, dishonesty or other improper purposes' and 'may be' on other grounds wider than jurisdictional error as understood with respect to prohibition and mandamus. Examples of what might be one of those 'other grounds' may be seen in two statements by Gaudron J. In Abebe $v$ Commonwealth ${ }^{51}$ her Honour said that while 'not every failure to have regard to relevant matters or to disregard irrelevant matters constitutes jurisdictional error', in the particular circumstances of a case such a failure may lead a tribunal wrongly to deny the existence of its jurisdiction or mistakenly to place limits on

[1993] AC 682, 696, 701-2, 705-6.

(1918) 25 CLR 241.

Difficulties resolved in England as late as Mv Home Office [1994] 1 AC 377; for Scotland see Davidson v Scottish Ministers 2006 SLT 110; [2005] UKHL 74.

Pape v Federal Commissioner of Taxation (2009) 238 CLR 1, 35 [50]-[51], 99 [273].

(1998) 194 CLR 247, 262 [37].

(1992) 175 CLR 564, 581-2, 595-6.

(2003) 211 CLR 476, 508 [82].

(1999) 197 CLR 510, 552 [107]-[108] ('Abebe'). 
its functions or powers; in those circumstances injunctive relief could be available under s $75(\mathrm{v})$.

Gaudron J referred to the above passage from Abebe in Muin $v$ Refugee Review Tribunal $^{52}$ when considering the operation of s 418 of the Migration Act 1958 (Cth). This section set out administrative procedures for review by the Refugee Review Tribunal of decisions under that statute. These procedures included provision to the Tribunal by the Secretary to the Department of certain documents. ${ }^{53}$ Her Honour indicated that a failure by the Secretary to comply with s 418(3) would not infect the decision of the Tribunal with jurisdictional error. But she added her opinion that: ${ }^{54}$

There is, in my view, no reason why injunctive relief pursuant to s 75(v) of the Constitution should be confined by notions of jurisdictional error. Thus, for example, were an applicant for review to seek an injunction restraining the Tribunal from proceeding to a decision until the documents referred to in s 418(3) of the Act were provided, it would be unnecessary to establish that the making of a decision would, in the absence of those documents, constitute jurisdictional error. Rather, it would be sufficient to establish that the documents had not been provided, that they might affect the decision and, perhaps, that they could not otherwise be obtained.

The actual decision in Muin turned on questions of procedural fairness and the remedies provided by the Full Court were prohibition, certiorari and mandamus.

As Professor Saunders has pointed out, ${ }^{55}$ sooner or later the Full Court is likely to be confronted by a s 75(v) proceeding, not based on jurisdictional error, where injunctive relief is not to be withheld on discretionary grounds.

\section{CONCLUSIONS}

We may never know with any precision what led to the omission of certiorari from what became s $75(\mathrm{v})$. The best surmise attributes this state of affairs to the knowledge of Inglis Clark of the state of United States judicial authority on the subject. ${ }^{56}$

With respect to injunctions we have at least the statement by Barton in the debate at Melbourne that without their inclusion in s 75(v) there would have been a question whether mandamus or prohibition would lie against a Commonwealth officer, given that 'any such proceeding as amounts to a proceeding against the Crown cannot be taken without an express Act to authorise it'. ${ }^{57}$ Quick and Garran saw as 'not quite apparent' the necessity to include injunctions in s $75(\mathrm{v})$, this ordinarily being a remedy 'in private suits between party and party', but, they added, perhaps it was to be seen as 'analogous' to mandamus. ${ }^{58}$ This overlooked the use of the injunctions in England to enforce public trusts and to protect private property against abuse by public authorities of statutory

52 (2002) 76 ALJR 966, 977 [46]-47] ('Muin').

53 Migration Act 1958 (Cth) s 418(3).

54 Cf the decision of Weinberg J in Lu v Minister for Immigration, Multicultural and Indigenous Affairs [2004] FCA 543, [30]-[33], [48]-[50], [61], in which a merits case unsuccessfully sought to be dressed in equitable clothing.

55 Cheryl Saunders, 'Constitution as Catalyst: Different Paths within Australian Administrative

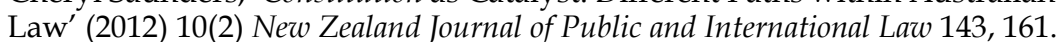

56 See Leeming, Authority to Decide, above n 9, 250.

57 Official Record of the Debates of the Australasian Federal Convention, Third Session, Melbourne, 1898, vol V, 1874-1875.

58 The Annotated Constitution of the Australian Commonwealth (Angus and Robertson, 1900) 783. 
powers. Further, in the United States the litigious life of successive Postmasters-General indicated the utility of the injunctive remedy against public officers.

In any event, we are not concerned to identity individual or collective 'intentions' of the framers of s 75(v) in the sense of any subjective understanding. Section 75(v) incorporated terms with a technical meaning and application in common law systems; the question is why certiorari was not a species of the same genus. An appropriate inquiry looks to the understanding of 'certiorari' and 'injunctions' as evidenced by the course of judicial decisions in the United States and England in the period before the adoption of the Australian Constitution. 
